Article

\title{
Responsive to the People? Comparing the European Cognitive Maps of Dutch Political Leaders and their Followers
}

\author{
Femke van Esch ${ }^{1, *}$, Rik Joosen ${ }^{1}$ and Sabine van Zuydam ${ }^{2}$ \\ ${ }^{1}$ Utrecht School of Governance, Utrecht University, 3511ZC Utrecht, The Netherlands; \\ E-Mails: f.a.w.j.vanesch@uu.nl (F.v.E.), m.c.joosen@uu.nl (R.J.) \\ ${ }^{2}$ Tilburg School of Politics and Public Administration, Tilburg University, 5037AB Tilburg, The Netherlands; \\ E-Mail: s.vanzuydam@tilburguniversity.edu \\ * Corresponding author
}

Submitted: 30 January 2016 | Accepted: 21 April 2016 | Published: 23 June 2016

\begin{abstract}
Political leaders are often perceived as unresponsive to the daily concerns of citizens, especially when European integration is concerned. Academic research, however, provides at most mixed evidence for the existence of such a gap. This article tries to shed light on this discrepancy by introducing an alternative measure to study leaders' responsiveness-narrative congruence-and explores the assumption that responsiveness increases leaders' credibility in the eyes of their voters. As narrative congruence is a more intricate measure that captures leaders' and followers' policy preferences and argumentation, it may better capture the gap between their positions and therefore provide a more adequate explanation for citizens' support for their leaders than traditional congruence measures like issue saliency and ideological distance. To provide a first test of this, the technique of cognitive mapping is introduced and used to explore the congruence in beliefs on European integration of four Dutch political leaders and their followers. Although the study finds a significant gap between some leaders and their followers' narratives on Europe, it finds no evidence that this narrative congruence is related to the credibility of these leaders in the eyes of their followers.
\end{abstract}

\section{Keywords}

cognitive mapping; credibility; European Union; narrative congruence; political leaders; responsiveness

\section{Issue}

This article is part of the issue "New Approaches to Political Leadership", edited by Mark Bennister (Canterbury Christ Church University, UK).

(C) 2016 by the authors; licensee Cogitatio (Lisbon, Portugal). This article is licensed under a Creative Commons Attribution 4.0 International License (CC BY).

\section{Introduction}

As democratic representatives, political leaders are expected to be responsive and able to relate to their followers' daily concerns (Flinders, 2012; Lijphart, 1999; Reicher, Haslam, \& Platow, 2014). After all, elected leaders are given a mandate by citizens to act on their behalf (Manin, 1997). According to democratic theory, political leaders respond to this need for responsiveness among others because of the threat of electoral sanction and moral obligation (Hobolt \& Klemmensen, 2005; Thomassen, 1994). There is thus an implicit as- sumption that responsiveness results in public support of party supporters for political leaders, for example in terms of perceived credibility (Jacobs \& Shapiro, 2000; Reicher et al., 2014).

While the extent to which leaders should follow and voice citizens' concerns is debated (Thomassen, 1994), surveys show citizens are dissatisfied with the responsiveness of their leaders who are regularly perceived as elitist and technocratic (Hay, 2007; Hendriks, Van der Krieken, Van Zuydam, \& Roelands, 2016; Reicher et al., 2014). In the public debate, the gap between political leaders and citizens' positions on the 
European Union (EU) is seen as especially pronounced. After decades of 'permissive consensus' in which citizens seemed content to leave European affairs in the hands of their leaders, the current public debate shows signs of a 'dismissive dissensus': European affairs have become highly polarised, Eurosceptic parties have won support, and trust in the EU has declined (De Wilde \& Zürn, 2012; Hooghe \& Marks, 2009; Van den Berg \& Van Eijk, 2012). Intriguingly, however, academic studies provide mixed evidence for the existence of a gap between leaders and their followers on European issues (Arnold, Sapir, \& Zapryanova, 2012; Carruba, 2001; Lindeboom, 2012; Steenbergen, Edwards, \& De Vries, 2007; cf. Dekker \& Den Ridder, 2011; Walczak \& Van der Brug, 2012). Both in terms of pro/anti-European or left/right ideological orientation as well as issue saliency, studies find a relatively close correspondence between government and citizens preferences. Still, a substantial group of citizens feel unheard by their political leaders (Hendriks et al., 2016).

This article therefore introduces an alternative type of congruence-narrative congruence-to study the responsiveness of political leaders' positions on the EU that might shed light on the discrepancy between citizens' dissatisfaction with their leaders and the relative high congruence found in many studies. In addition, we explore whether congruence indeed coincides with attributed credibility to political leaders. This article thus aims to answer the question whether narrative congruence exists between political leaders and their followers and if this form of congruence fosters leaders' credibility ratings. To answer this question, the technique of cognitive mapping is used. Unlike the more common elite interviews and surveys, this technique allows us to determine traditional congruence measures like issue saliency and ideological distance as well as the overlap in the narratives in which leaders' and followers' positions are rooted. Moreover, in contrast to traditional narrative analyses, cognitive mapping allows the narratives of large groups of citizens to be studied and aggregated (Gaxie, Hubé, \& Rowell, 2011; Van Inglegom, 2014).

Empirically this article focuses on Dutch EU politics as a first test of the concept and measure of narrative congruence and its effects on leaders' credibility. Since the Dutch 'no' to the European constitution in 2005, a lack of trust in EU politics has become a prevalent phenomenon for the traditionally pro-European Dutch. Combined with the notion that The Netherlands has one of the most proportional representative political systems in the world-increasing the chance of finding a political leader who is responsive to your beliefs (Golder \& Stramsky, 2010; Hobolt \& Klemmensen, 2005)-it constitutes a critical case for responsive EU leadership and is therefore interesting for a first probe into a new concept and method. Specifically, in this study the European beliefs of four Dutch political lead- ers most visible in the debate in the months surrounding the 2014 EP elections are traced: the Liberal Prime Minister Mark Rutte, the Social-Democrat minister of foreign affairs Frans Timmermans and the two main opposition leaders Alexander Pechtold of the proEuropean Liberal Democrats and Geert Wilders of the Eurosceptic Freedom Party. A focus on these leaders ensures balance and variety across the political landscape and maximizes what we can learn from this study (Stake, 1995). The 2014 EP elections increased political attention for the EU and situating our study in the months surrounding this event enabled us to source enough speeches in which the four leaders address the issue at stake.

\section{Responsive Leadership in a European Setting}

In recent decades, Europe has taken centre stage in the public debate in many member states. After decades of 'permissive consensus', the current public debate is characterised by a high degree of polarisation. Increasingly, the domestic political agenda is occupied by European issues (Hooghe \& Marks, 2009). Despite attempts of political leaders to depoliticize the public debate, the increasing competences of the EU, competitive party politics, and several crises have pushed the EU centre stage (De Wilde \& Zürn, 2012). While for decades the 'Europhile' elite has claimed to know what kind of Europe was best for its citizens (Startin \& Krouwel, 2013), presently Euro sceptics insist they voice citizens' true concerns. For both normative and empirical reasons, it is thus important to examine the extent to which leaders are responsive to the peoples' preferences in the European domain.

Despite widespread concerns about the gap between citizens and political elites, most empirical studies 'find very little evidence for allegations that political elites are out of step with the masses when it comes to EU policies' (Steenbergen et al., 2007, p.30; cf. Arnold et al., 2012; Dekker \& Den Ridder, 2011; Walczak \& Van der Brug, 2012). This seems to be the case both in terms of the pro/anti-European positions, left/right ideological leanings as well as the prioritisation of issues. However, within this general pattern, national, partisan, and individual-level variations in the strength of the party/voter connection do exist (Best, Budge, \& Mcdonald, 2012; Ray 2003; Steenbergen et al., 2007): the congruence between leaders and the public is stronger in proportional representative systems. Moreover, the likeliness of voters adopting party elites' positions is increased when the voter is highly attached to the party (Lindeboom, 2012; Ray, 2003). Finally, Carruba (2001) finds that while overall they approximate the public's preferences, elites generally take more extreme positions. The state of the art in academic research is thus all but conclusive about the gap between political elites and their constituents that features so 
dominantly in the public debate on Europe. In this paper, we introduce a different way of looking at congruence that may shed light on this discrepancy.

The dominant way to measure leader-follower congruence in academic literature is to establish the overlap in issue saliency and ideological distance (Golder \& Stramsky, 2010; Hobolt \& Klemmensen, 2005; Lindeboom, 2012). Overlap in issue saliency concerns the extent to which leaders and voters agree on what issues are most important and pressing and should be prioritized (Verba \& Nie, 1972). Ideological distance refers to the extent to which leaders and voters share a position on an ideological scale like the traditional left/right or pro/anti EU scale. Both measures are usually established through large-scale survey research like the Eurobarometer.

These measures, however, are limited in three ways. Firstly, congruence in issue saliency may establish whether leaders and their followers see the same issue as important, but does not indicate whether it is perceived as positive or negative, why it is seen as salient or how it should be solved. Ideological distance does suggest a very broad preferred policy direction but is unable to reveal whether leaders and followers agree on specific measures or why. In addition, the survey-questions used to establish issue saliency and ideological distance have the disadvantage of being formulated top-down by the researcher and not allowing citizens much room to tell their own stories. Moreover, survey questions are often one-dimensional and do not allow for nuanced or ambivalent responses (Schaffer, 2010), nor do they tap into the substantive reasoning and rationale behind people's perceptions on contentious issues (Gaxie et al., 2011; Van Inglegom, 2014).

In this paper, we introduce a third and more intricate measure of congruence: narrative congruence. This measure captures leaders' and followers' evaluation of the issues they raise, and their preferred direction for solution. In addition, narrative congruence is a more qualitative measure that tracks the arguments and storylines used by leaders and citizens to support their position. As it delves deeper into the way people make sense of the world, this measure potentially offers a more powerful reflection of their European beliefs.

The three forms of congruence are compatible and hierarchically organized in terms of how detailed and far-reaching the meeting of minds is that they measure (see Figure 1). While congruence in issue saliency indicates that there is a shared concern and ideological congruence signals actors' general political leanings, narrative congruence builds on this information and adds knowledge concerning why actors perceive issues as positive or negative, how different issues relate to one another, and specifies actors' preferences on specific directions for solution. The higher leaders climb in this hierarchy of congruence, the more intricate and complete the overlap with their followers' views will be. Moreover, as democratic theory suggests, this may mean that it is more closely related to the support leaders receive.

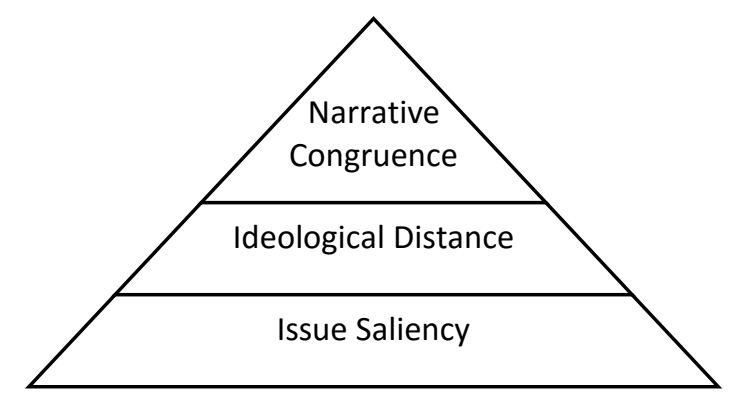

Figure 1. Hierarchy of congruence.

In studies on congruence, only limited attention has been paid to its consequences for citizens' support (Esaiasson \& Wlezien, 2016), even though the relationship is often implicitly assumed. Public support may entail many different things, like citizens' satisfaction with leaders' actions or confidence in their leadership (Levi \& Stoker, 2000; Miller \& Listhaug, 1999; Norris, 2011). This study focuses on credibility as an indicator of followers' support because it is most closely related to congruence. Studies show, for instance, that the more leaders voice peoples' thoughts, the more convincing their problem analysis and concern for citizens' views are (cf. Mayne \& Hakhverdian, forthcoming). Credibility consists of three dimensions: perceived competence, trustworthiness, and caring (Berlo, Lemert, \& Mertz, 1969). Competence relates to leaders' knowledge and skills: do citizens think they offer the right problem analysis and know what needs to be done (O'Keefe, 1990)? Trustworthiness entails whether voters believe leaders are honest and reliable (Hovland, Janis, \& Kelley, 1953). Caring means that leaders are empathetic towards their voters' problems, and that they take their interests at heart (McCroskey \& Teven, 1999). Of the three dimensions, caring in particular seems relevant, as it deals specifically with the question of whether voters feel their leaders relate to their concerns.

\section{Methods}

The different levels of congruence between leaders' and citizens' narratives of Europe will be established using the technique of cognitive mapping, while citizens' support for the party leaders is determined through survey-research.

\subsection{Cognitive Mapping}

Cognitive mapping is used in political science, social psychology and organizational studies to uncover peoples' beliefs (Axelrod, 1976; Bougon, Weick, \& Brink- 
horst, 1977; Van Esch, 2014; Young \& Schafer, 1998). Cognitive maps consist of concepts and the causal and utility relationships between them that together make up an actor's belief system. Causal relations refer to the relationship between cause and effect or means and ends, while utility relations determine whether a concept is valued positively or negatively in a normative sense. When these concepts and relations are represented graphically, the concepts are depicted as points and the relations as arrows (see Figure 2). ${ }^{1}$

The cognitive maps of Dutch citizens were derived from a sample of 300 adults, enlisted randomly via a commercial polling agency. The maps were elicited directly via the web application DART, from two weeks prior to the European Parliament elections of May 2014 until a week after. A freehand approach was used as this is the most efficient and valid way (Hodgkinson, Maule, \& Bown, 2004). Respondents were first asked to select seven out of a list of 50 pre-defined concepts that in a pilot were found to be associated with European integration by Dutch citizens and experts. Subse-

${ }^{1}$ Figures 2-5 show an excerpt of the leaders' maps using only the concepts also present in the maps of their followers, indicating the overlapping relations in dark-grey arrows. Only the most salient relations from the voters' map are shown in light-grey arrows with the exact limit dependent on the size of the map. quently, respondents drew arrows between the concepts to indicate how, in their eyes, these concepts were linked. The direction of the arrow indicates the direction of the causal effect (cause $\rightarrow$ effect) while the colour of the arrow indicates whether the effect is deemed to be positive (green) or negative (red). This allowed respondents a choice of nearly 5000 different relations to compose their cognitive map from. In addition, respondents were asked to complete a short survey about their demographic characteristics and political behaviour. Respondents' answers concerning the party they intended to vote for in the 2014 EP elections were used to aggregate their individual cognitive maps into a collective map of the followers of the respective party leader. This focus on party supporters results from our interest in the responsiveness of political leaders to their constituents' views.

The cognitive maps of the Dutch national political leaders are based on three public speeches or interviews concerning Europe held between 03-11-2012 and 02-09-2014. Only speeches that addressed the EU specifically and substantially were selected until enough data was gathered to draw a cognitive map from. ${ }^{2}$

\footnotetext{
${ }^{2}$ For the leader of the Social-Democrat party, Diederik Samsom, not enough data was available. For Pechtold, the party bureau was contacted to obtain enough speeches.
}

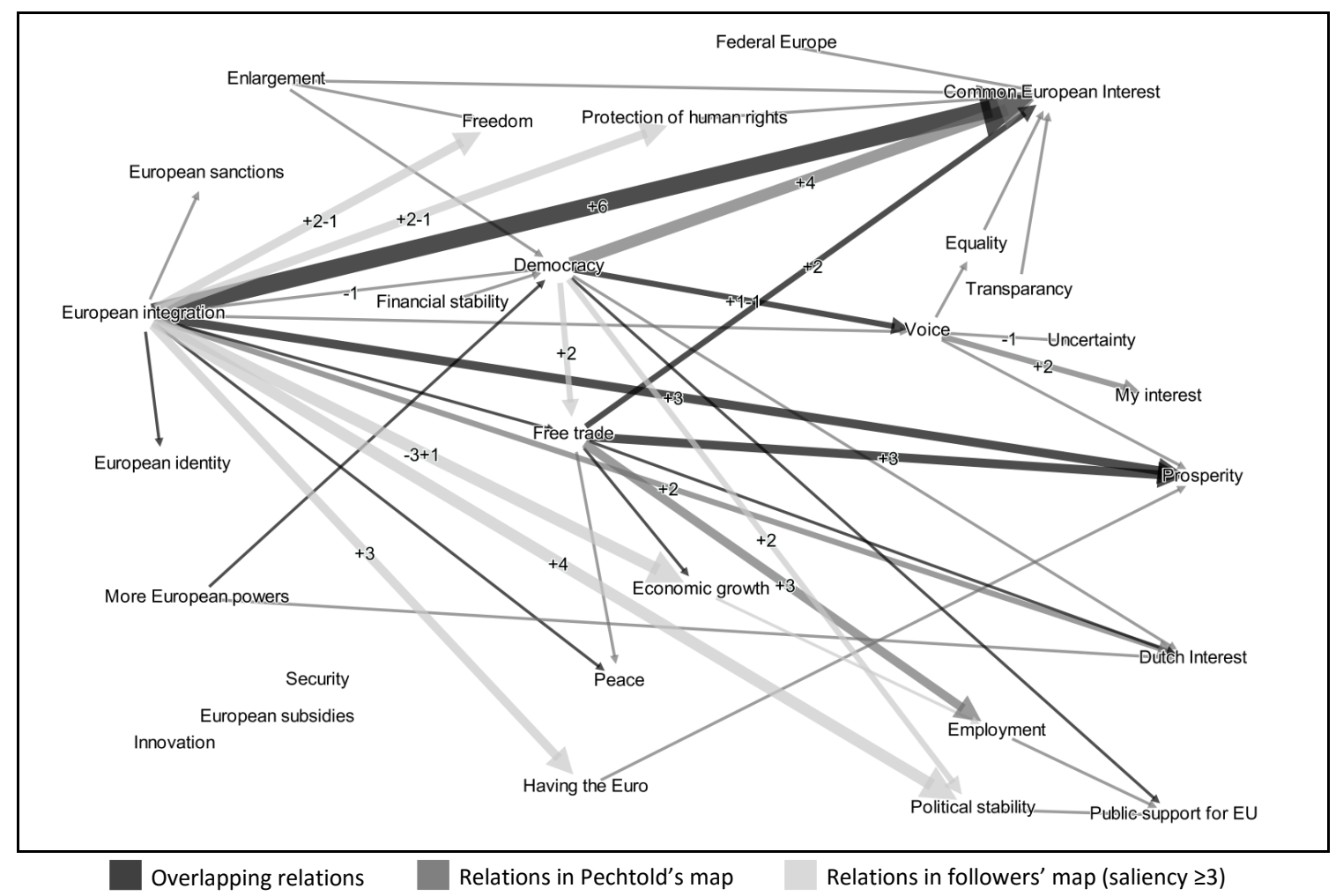

Figure 2. Combined excerpt from the cognitive map of Pechtold and D66 voters. Source: Pechtold (2012, 2014a, 2014b). 
The selection thus represents the limited available data from the period surrounding the 2014 EP elections. To create the cognitive maps, causal and utility relationships alluded to by leaders are manually coded from the selected texts, the coding was transparently and digitally documented in CM software MAPS. ${ }^{3}$ To make comparison between the leaders' and citizens' maps possible, concepts in the maps of the leaders were standardised using the same 50 pre-defined concepts presented to the citizens (Laukkanen \& Wang, 2015). The standardisation results in an abstraction of the leaders' views that ensures that the map is a reflection of their more general view of European integration. An additional 32 concepts were identified in the speeches of the leaders that represented distinctly different issues than those presented to their constituents. To draw the maps, network software Gephi was used (Bastian, Heymann, \& Jacomy, 2009). All in all, this resulted in maps of 83 to 180 relations per leader.

Cognitive maps can be analysed in various ways. The relative strength of ideas is established by their saliency $(S)$-the frequency with which they are mentioned. The more salient a relation, the larger it appears in the map (see Figure 2). In addition, scholars may study the 'consequent paths' feeding out of a concept into other concepts as well as the value of these relations (positive, negative, non-existent). ${ }^{4}$ These analyses inform leaders' scores on the three different forms of congruence. Congruence in issue saliency was measured by establishing the overlap of the concepts used by the leaders and voters and the overlap in how salient these concepts were in their maps. The average of these two is taken as the measure of issue saliency. With regard to ideological distance, the paper focuses on the pro/anti EU dimension. To calculate this measure, we categorised all concepts as pro-European (for instance: the Euro), anti-European (splitting up the EU) or EU-neutral (political stability), and as generally positive (social justice), negative (recession) and neutral (debate). ${ }^{5}$ The pro/anti EU scale was constructed by at-

\footnotetext{
${ }^{3}$ For the CM coding rules, see Wrightson (1976). All texts were double coded by two of the authors.

${ }^{4}$ The value of a relationship (positive, negative, non-existent) is indicated by $a+,-$ or 0 . Only negative saliency scores and those above 1 are noted in Figures $2-5$. Concepts linked via a positive consequent path to a positively valued concept, or via a negative consequent path to a negative concept are positive. Concepts positively feeding into a negative concept, or negatively feeding into a positive concept are negative.

${ }^{5}$ Two coders (including one of the authors) categorized the 50 pre-set concepts independently in the realm of another study. Two of the authors independently coded the 32 additional concepts from the leaders' maps. Overall, the intercoder reliability of the European/Anti-European and Positive/Negative dimensions was respectively 0,96 and 0,71 (Cohen's Kappa) representing an excellent and good intercoder reliability (Gwet, 2012).
}

tributing one point to the scale when a causal relation implied a positive reference to the EU and deducting one point when a causal relation implied a negative reference to the EU. Finally, this score was divided through the total number of times European concepts were connected to come up with a comparative measure that ranges from -1 to 1 . The difference between the scores of the leaders and followers results in the ideological distance. The narrative congruence between the leaders and their followers is established by qualitatively comparing leaders' and followers' maps. To structure this analysis, we followed four steps. Firstly, we established how many direct relations between two concepts are identical in the leaders' and follows' map. In addition, salient (indirect) relations linking multiple concepts were compared to see if leaders and followers arrive at similar conclusions. The third step involved a search for directly contradicting arguments. Finally, by analysing the utility relations, we established the overlap in how leaders and followers evaluated the shared concepts in their maps. Although quantification cannot capture the full meaning of this analysis and the indirect relations are only studied qualitatively, some frequencies are provided as a tentative proxy for the outcome of this analysis. As the technique of cognitive mapping has not been used to measure congruence before, for all measures, leaders' ranking is used to determine what scores are interpreted as high or low.

\subsection{Measuring Support through Survey Research}

The credibility of Pechtold, Rutte, Timmermans and Wilders was derived from an existing survey on credible political leadership that was administered by CenterData to the LISS panel (Van Zuydam, 2014). This panel provides a representative sample of the Dutch population. In the survey, 3295 respondents were asked to evaluate all cabinet ministers of cabinet Rutte II and parliamentary party leaders active at the same time. The questionnaire was administered three times: in August 2013, January 2014, and June 2014. The response rate was respectively $78.5,82.2$ and 81.5 percent. Four leaders were randomly selected for each respondent to evaluate. Cross referencing the leaders evaluated by the respondents with their vote in the 2014 European elections resulted in a subset of 36 to 56 evaluations for each of the four leaders in this study.

We measured the credibility of the leaders on three dimensions: their perceived competence, trustworthiness, and caring in the eyes of their (potential) voters. For each leader they professed to know, respondents were presented six Likert items (6-point with in addition a "don't know" answer); two for each credibility dimension. The responses on these items in the three waves were integrated, which resulted in an average overall score for each respondent on each of the six items. Subsequently, the answers for each dimension 
were combined into an additive scale, resulting in three indices for each leader: a competence, trustworthiness, and caring index. Chronbach's $\alpha$ based on the aggregative, overall score for each studied leader and each index-in total thus 12 indices-was in most cases between 0.8, and 0.96. Only twice was Chronbach's $\alpha$ lower at 0.786 and 0.794 . In addition, a total credibility index was calculated if valid responses on at least four of the six items were available. Chronbach's $\alpha$ for this scale ranged between 0.914 and 0.962 for all four leaders. These indices were used to establish leaders' credibility according to citizens.

\section{Congruence}

\subsection{Issue Saliency and Ideological Distance}

The cognitive maps of Alexander Pechtold and his followers scored highest in terms of issue saliency congruence. Of the 39 concepts used by Pechtold, 28 are also present in the map of the supporters of his party. In 57 percent of these cases, they also agree on the relative saliency (in terms of relative rank) of the issues (see Table 1). This agreement covers key concepts like European integration, the common European interest and democracy. D66 voters are, however, much more concerned about economic political stability, economic growth, freedom and peace than Pechtold, who rates free trade as more salient. The beliefs of Mark Rutte are slightly less representative of his supporters' at an overlap of 26 issues. This amounts to 68 percent congruence, but does not include issues salient to his voters like the Euro, labour-migration or human rights. Their mutual agreement on the relative saliency of the shared concerns is only 54 percent and also predominantly involves low-saliency concepts.

Geert Wilders ranks third with a concept overlap of 64 percent of his map. This congruence includes salient concepts to his followers like recession, the Dutch interest, having the Euro and the Dutch exit from the EU.
The overlap in issue saliency is, however, only 50 percent and includes only low ranking concepts. Former minister of Foreign Affairs, Timmermans, has the lowest score in issue saliency overlap: despite the high number of concepts (58) in his map, the concept overlap is only 50 percent. In terms of relative saliency Timmermans' speech-acts are also the least representative at a score of 36 percent. While Timmermans is more concerned with solidarity, European identity and the status of the EU in the world, his voters stress issues like economic growth, peace, social security, equality and political stability.

The leaders and their followers also differ considerably on their evaluation of the EU measured in terms of ideological distance (see Table 2). Although the leaders and their followers agree on whether they are pro- or anti-European, in all instances the leaders hold stronger views. Even Rutte, who is closest to his voters with a difference of 0.15 , is more positive than his followers. Pechtold's score is 0.23 more positive than his voters and Timmerman's score exceeds his followers' by almost double that. The most extreme difference is found for Wilders, who is the only leader with a clear anti-EU perspective, at a hefty 0.84 points more antiEuropean than his followers.

Overall, these findings show that congruence in terms of issue saliency for these leaders and followers is at a reasonable level and only dips below 50 percent for Timmermans. The scores on ideological distance corroborate the conclusions of previous studies as they reveal similar ideological leanings between leaders and followers with the leaders taking more-and sometimes far more-extreme positions (Carruba, 2001). However, moving up in the hierarchy of congruence also reveals a declining level of congruence. This raises the question whether studying the narratives underlying leaders and followers' positions may reveal further dissonance and reflect the feeling of disjunction reported by Dutch voters.

Table 1. Issue saliency congruence (score and rank).

\begin{tabular}{|c|c|c|c|}
\hline Leader Issue Saliency & $\begin{array}{l}\text { Concept overlap } \\
\text { (\% of leader's map) }\end{array}$ & $\begin{array}{l}\text { Saliency Overlap } \\
\text { (\% in relative rank) }\end{array}$ & Average \\
\hline Pechtold-D66 & $72(1)$ & $57(1)$ & $64.5(1)$ \\
\hline Rutte-VVD & $68(2)$ & $54(2)$ & $60.0(2)$ \\
\hline Wilders-PVV & $64(3)$ & $50(3)$ & $57.0(3)$ \\
\hline Timmermans-PvdA & $50(4)$ & $36(4)$ & $42.0(4)$ \\
\hline
\end{tabular}

Table 2. Ideological distance (score and rank).

\begin{tabular}{llll}
\hline & Leader & Followers & Ideological Distance \\
\hline Rutte-VVD & 0,69 & 0,54 & $0,15(1)$ \\
Pechtold-D66 & 0,79 & 0,56 & $0,23(2)$ \\
Timmermans-PvdA & 0,9 & 0,46 & $0,44(3)$ \\
Wilders-PVV & $-0,84$ & $-0,0049$ & $0,84(4)$ \\
\hline
\end{tabular}




\subsection{Narrative Congruence}

Reviewing the cognitive maps in a qualitative and holistic manner by looking at the causal and utility relations, reveals that the narrative congruence between Pechtold and the D66 voters is the highest amongst our set of leaders (Table 3). Of the 57 unique direct relations between concepts, twelve are also present in his followers' map, whereby the positive links between European integration, the common European interest and prosperity as well as between free-trade, prosperity, democracy and voice are the most salient to Pechtold (Figure 2). Moreover, agreement exists on the positive effect of European integration on peace and that freetrade is in the common European interest, arguments that are salient in the mind of the D66 voters. It is therefore clear that both Pechtold and his followers are principled pro-Europeans for many of the same reasons. The D66 voters, however, also support the EU because it fosters political stability, freedom, the protection of human rights and has led to the establishment of the euro. In Pechtold's mind, these effects are also positively but only indirectly associated with the EU. Moreover, when taking into account the indirect relations in the maps, more similarities appear. Firstly, Pechtold states that by fostering free trade the EU not only promotes economic growth, but also peace, and employment and thereby public support for the EU. His supporters agree with this positive evaluation of free trade for similar reasons, with part of the effects being mediated by the existence of the Euro which in their eyes provides a strong argument in favour of European integration, as it fosters free trade, freedom, and economic growth.

There is, however, one marked contradiction between Pechtold's and his followers' narrative on Europe: their evaluation of the relationship between European integration and democracy. While the D66 voters feel Europe contributes positively to democracy, Pechtold identifies a negative relationship. Democracy is a positive value and salient concern for both Pechtold and his supporters: they agree that democracy provides citizens with the opportunity to participate and voice their preferences, and while Pechtold feels that having a voice in politics brings equality, prosperity and is in peoples' interest, his followers positively relate democracy to political stability and free trade. The contradiction in their belief of how the EU affects democracy is therefore an important one, although Pechtold and his voters agree that increasing the EU's powers will enhance democracy.

Finally, reviewing the normative dimension of the narratives by analysing the utility statements of Pechtold and the D66 followers, reveals an overlap of 82 percent in their evaluation of shared concepts. Overall, the cognitive map of Pechtold thus shows a reasonable level of narrative congruence with the map of his followers.

The maps of Rutte and his followers contain eight identical relations (Figure 3). Firstly, their mild support of European integration relies in part on their shared belief that European integration serves both the Dutch and the common European interest. Moreover, Rutte believes that the EU stimulates free trade, which positively affects economic growth, which is in the common European interest and ultimately promotes prosperity. This exact line of reasoning is found in the narrative of the VVD voters, although it is less salient to them. Moreover, both maps contain the argument that recession has a negative effect on prosperity and the liberal idea that freedom is in the best interest of The Netherlands. The most noticeable difference is that Rutte makes no mention of the Euro while this is one of the most salient concepts in the mind of the VVD voters. They are ambiguous about its value, however, as they consider the Euro to positively contribute to economic growth, but to have an overall negative effect on prosperity. In contrast to Rutte, their overall assessment of the EU on prosperity is thereby negative. The one direct contradiction in the map of Rutte and his followers also concerns the economic effects of the EU and lies in the fact that Rutte feels European integration has no effect on financial stability, while his voters feel it has a positive effect.

Table 3. Narrative congruence (score and rank).

\begin{tabular}{lllll}
\hline Leader & Narrative Congruence & $\begin{array}{l}\text { Direct relation } \\
\text { overlap }\end{array}$ & $\begin{array}{l}\text { Direct relation } \\
\text { contradiction }\end{array}$ & $\begin{array}{l}\text { Evaluation overlap Overall } \\
\text { (\% of shared } \\
\text { concepts) }\end{array}$ \\
\hline Pechtold-D66 & $12 / 57(1)$ & $1 / 57(2)$ & $82(1)$ & $4(1)$ \\
Rutte-VVD & $8 / 99(3)$ & $1 / 99(1)$ & $73(3)$ & $7(2)$ \\
Wilders-PVV & $8 / 81(2)$ & $3 / 81(4)$ & $79(2)$ & $8(3)$ \\
Timmermans-PvdA & $7 / 130(4)$ & $3 / 130(3)$ & $69(4)$ & $11(4)$ \\
\hline
\end{tabular}




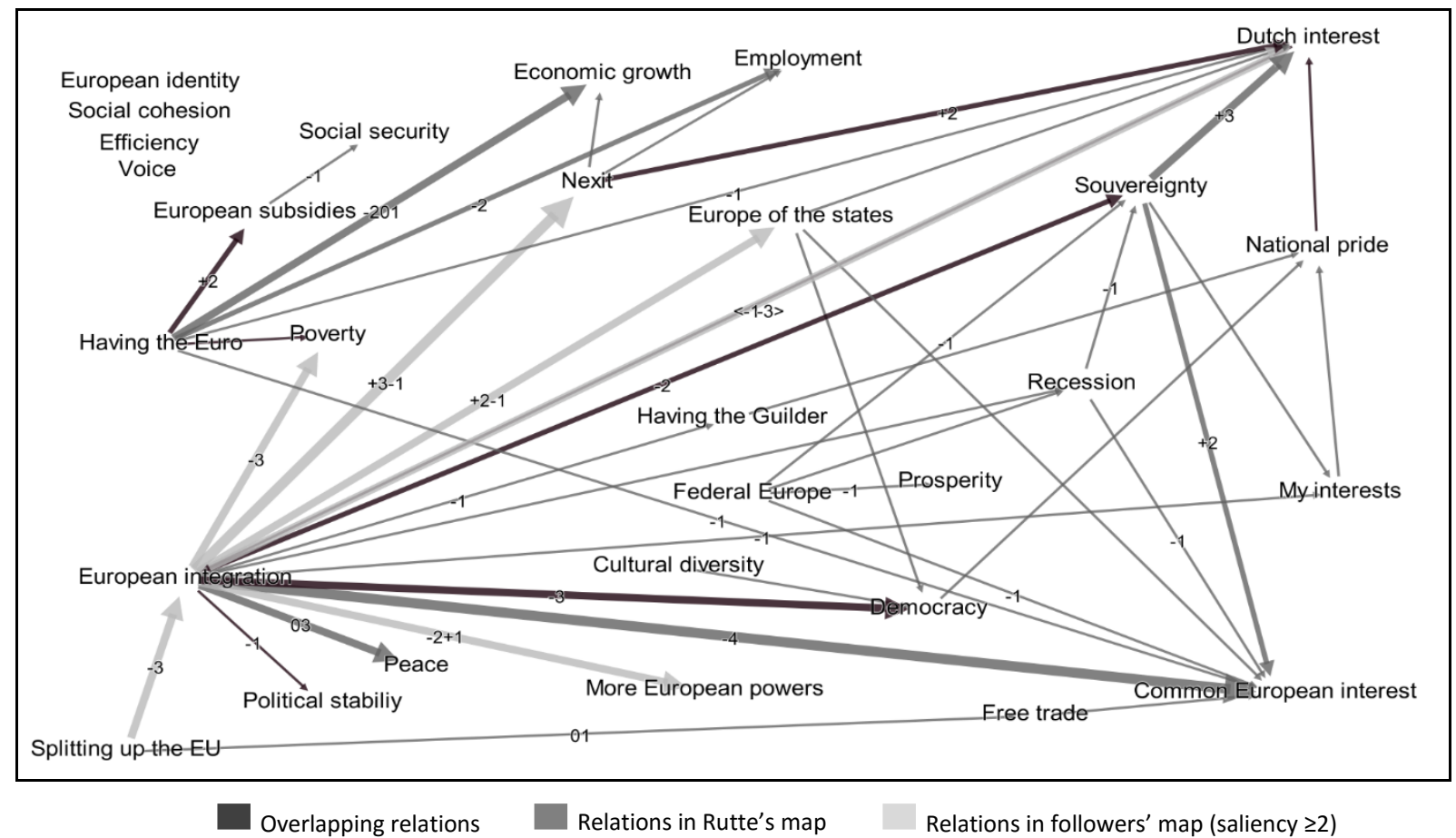

Figure 3. Combined excerpt from the cognitive map of Rutte and VVD voters. Source: Rutte (2013, 2014a, 2014b).

Overall, the VVD voters also identify much more noneconomic benefits of Europe than their leader, such as: equality, social cohesion, political stability and democracy.

A further indirect similarity in argumentation relates to the type of Europe Rutte and his followers envision. In his speeches, Rutte speaks abundantly about subsidiarity which he positively associates with innovation, free trade, efficiency and employment. The centrality of this concept in his map indicates that Rutte favours a strong autonomous role for the member states and generally objects to giving Europe more powers. His supporters think a federal Europe would enhance political stability and social cohesion, but overall also favour an intergovernmental Europe. They associate European integration predominantly with the concept 'Europe of the states' which they feel is strongly in the European interest, and they identify drawbacks to European leadership and an increase in European powers.

In terms of the normative evaluation of the shared issues in their maps, Rutte and his followers value 73 percent of the concepts the same. This congruence concerns concepts that are very salient to the voters, and contributes to Rutte's scores on narrative congruence. Overall his score is thereby considerable but still substantially lower than Pechtold's.

Wilders' narrative congruence with his followers is similar and only slightly lower than that of Rutte. Of the 81 unique direct relations in his map, eight are also present in the map of his supporters. Reflecting their shared Eurosceptic attitude these relations include the argument that European integration is against the
Dutch interest as it leads to a loss of sovereignty, democracy, and political stability as well as that national pride is in the Dutch interest (Figure 4). The PVV supporters also identify several positive consequences of the $\mathrm{EU}$, one being that it reduces poverty. Yet overall they share their party leader's negative assessment of the EU and agree that leaving the Union (Nexit) would serve the Dutch interest. While Wilders feels a Nexit would stimulate economic growth and employment, his supporters argue it would counter the recession and increase Dutch sovereignty. Some PVV voters fear, however, that leaving the EU could lower Dutch national pride and increase poverty. Finally, the PVV leader and his followers also share the idea that the Euro is not in the common European interest as it increases poverty and induces the provision of aid to other states. However, while Wilders only identifies negative effects of the introduction of the Euro, his supporters also see some benefits as, in their mind, it stimulates free trade and thereby economic growth. Overall Wilders and his followers share a negative evaluation of the Euro, and wish the Dutch would have retained their national currency. While Wilders feels this would have increased the Dutch national sense of pride, his followers argue it would have safeguarded financial stability.

Apart from the eight overlapping relations, the maps of Wilders and his followers contain three contrasting claims. Firstly, while Wilders denies a relationship exists between European integration and peace, his supporters argue the EU did foster peace. In addition, a direct contradiction exists between Wilders' argument that European integration has contributed to 


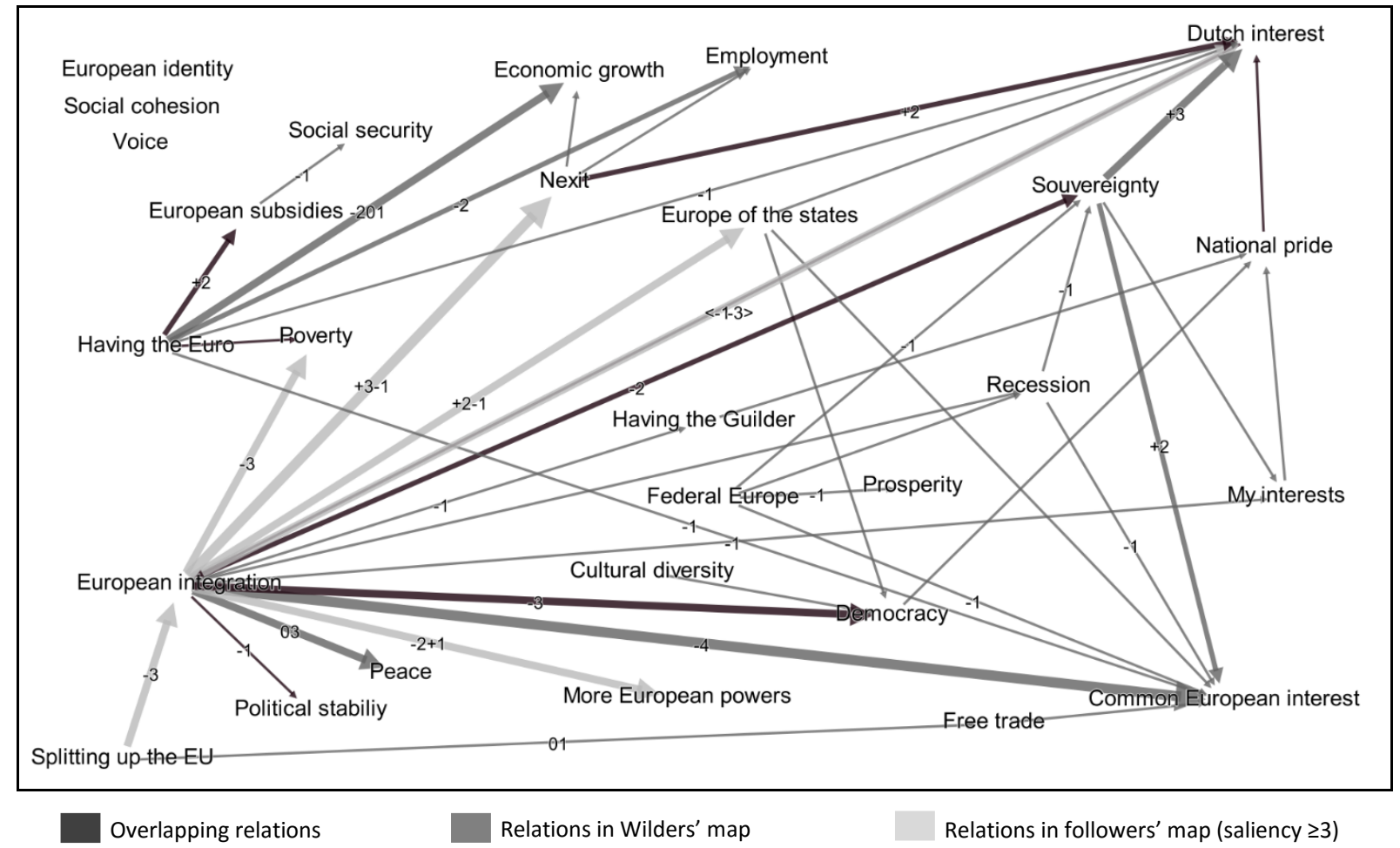

Figure 4. Combined excerpt from the cognitive map of Wilders and PVV voters. Source: Wilders (2013, 2014a, 2014b).

the recession and his followers' positive assessment of the EU's effect. Finally, while the PVV supporters feel the EU is neither in their own nor the Dutch interest, some feel it does serve the common European interest whereas Wilders is adamant that it does not. However, since all of these concepts and relations are not very salient to either map, the differences are relatively inconsequential for the broader narrative congruence.

Further evidence of a reasonable level of narrative congruence is provided by the relatively high overlap (79 percent) in how Wilders and his followers evaluate the concepts they share. So, although Wilders focusses more on the issue of sovereignty and democracy, and his supporters take a predominantly economic viewin terms of narrative - their views of Europe still show a reasonable alignment.

Finally, there is a stark difference in Timmerman's narrative on Europe and that of his supporters. Firstly, of the 130 unique relations in his map only seven find an exact match in the map of the PvdA voters, while in three instances a direct contradiction exists (Figure 5). Amongst the seven overlapping relations are the arguments that European integration fosters peace, the protection of human rights and equality, as well as increases the powers of the EU. However, while Timmermans feels the EU fosters economic growth his supporters are ambiguous about the effects of European integration on economic growth. They do agree with their leader that free trade leads to economic growth, but in contrast to Timmermans do not associate free trade with European integration in any way.
Furthermore, Timmermans also sees positive associations between the EU and social security, political stability, freedom, and the opportunity for people to voice their concerns whereas his supporters do not.

What broadens the divide even further is that the PvdA voters in our sample were very concerned about the Euro, which in their eyes had a positive impact on economic growth and efficiency but a negative effect on social justice, free trade, freedom, and sovereignty. Timmermans, however, makes no mention of the Euro. Timmermans and his followers do agree, however, that (more) European integration and an increased status in the world would promote financial stability and security. Additional differences result from Timmermans' strong association of European integration with solidarity. In his view solidarity fosters European integration and is in the common European and Dutch national interest. Solidarity also informs the formation of a European identity, increases financial stability and Europe's status in the world, which in turn fosters political stability and security. In contrast, the PvdA voters in our sample mention solidarity only once, and feel European integration has in fact reduced solidarity. Finally, the considerable divergence in Timmermans and his followers' narrative on Europe integration is illustrated by the fact that they do not share his strong belief that the $\mathrm{EU}$ is a major contributor to the common European and Dutch national interest.

The differences in argumentation already signals a stronger divergence in how Timmermans and his supporters value the topics they both discuss compared to 


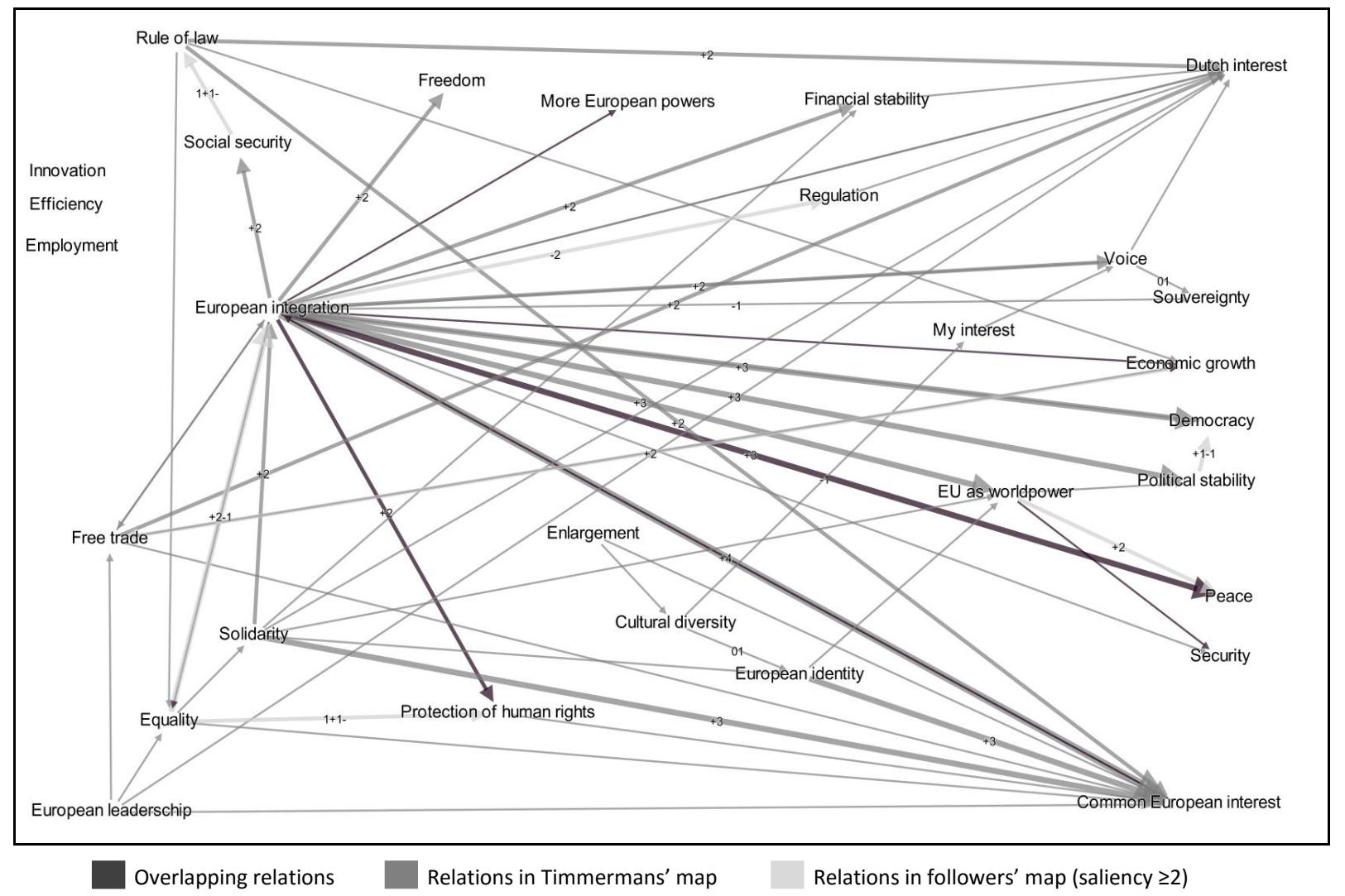

Figure 5. Combined excerpt from the cognitive map of Timmermans and PvdA voters. Source: Timmermans (2013, 2014a, 2014b).

other leaders. Moreover, the differences include several issues that are salient in the minds of the PvdA voters like social security, protection of human rights, equality and free trade. Thereby the overlap between the European narratives of Timmermans and his followers show the most considerable differences in this study.

Looking at the narrative congruence for all leaders, it stands out that the direct overlap in relations is low. However, at the same time these leaders also hardly directly contradict their followers. Looking beyond the direct causal relations, our analysis shows that by displaying a holistic image of their views a more in-depth comparison between leaders and voters is possible. The analysis reveals for instance that Pechtold and his followers are staunch advocates of European integration because of its positive economic effects but that they disagree about its consequences for democracy. Rutte and his followers also agree that the EU improves the Dutch economy, but favour a Europe of the states and disagree on the role of the Euro. For Wilders, his stronger opposition to the EU than that of his followers was also traced back to the fact that the PVV voters identify several positive effects of the EU and Euro where Wilders sees none. For Timmermans, the source of the divergence between his narrative and that of his followers emerges from their different views on the effects of European integration on economic growth and free trade, and the role of solidarity. Finally, the analysis suggests that convergence in argumentation fosters alignment in terms of normative worldview.

\subsection{Credibility}

Turning to the credibility of the four leaders in the eyes of their supporters, our analysis reveals that Timmermans' average perceived competence, trustworthiness, and caring score ranges between 9.46 and 10.16, ranking him first on all three dimensions. Consequently, his credibility ratings can be considered to be high to very high. This high standing includes the caring dimension which means that Timmermans is considered to connect especially well with his party's supporters' concerns and ideas. Rutte's attributed scores on the three dimensions range between 8.22 and 9.21 (Table 4), a high score. Moreover, his perceived caring is also relatively high according to his voters, meaning they feel Rutte empathizes with their concerns.

In Pechtold's case, the scores awarded to his competence, trustworthiness, and caring range between 7.55 and 9.31. While he is thus attributed less credibility than Timmermans and Rutte, his credibility is still medium to high. A closer look at Pechtold's evaluations reveals that his perceived caring scores lowest of the three dimensions, meaning that his party's supporters are not fully convinced that he understands their concerns and ideas. 
Table 4. Perceived credibility of the leaders (in score and rank).

\begin{tabular}{|c|c|c|c|c|c|c|c|c|}
\hline & \multicolumn{2}{|c|}{ Competence } & \multicolumn{2}{|c|}{ Trustworthiness } & \multicolumn{2}{|l|}{ Caring } & \multicolumn{2}{|c|}{ Overall credibility } \\
\hline & Mean & SD & Mean & SD & Mean & SD & Mean & SD \\
\hline Timmermans & $10,16(1)$ & 2,04 & $9,67(1)$ & 2,14 & $9,46(1)$ & 2,48 & $28,24(1)$ & 6,8 \\
\hline Rutte & $9,21(3)$ & 2,24 & $8,44(3)$ & 2,7 & $8,22(2)$ & 2,53 & $25,66(2)$ & 7,15 \\
\hline Pechtold & $9,31(2)$ & 2,39 & $8,72(2)$ & 2,24 & $7,55(3)$ & 2,67 & $24,72(3)$ & 7,1 \\
\hline Wilders & $7,63(4)$ & 3,31 & $7,02(4)$ & 3,59 & $6,99(4)$ & 3,65 & $21,32(4)$ & 10,05 \\
\hline
\end{tabular}

Note: Credibility dimensions range between 2 and 12, total credibility between 4 and 36 .

Table 5. Summary of all the scores on congruence and credibility (in rank).

\begin{tabular}{llllll}
\hline & $\begin{array}{l}\text { Issue } \\
\text { Saliency }\end{array}$ & $\begin{array}{l}\text { Ideological } \\
\text { distance }\end{array}$ & $\begin{array}{l}\text { Narrative } \\
\text { congruence }\end{array}$ & $\begin{array}{l}\text { Overall } \\
\text { congruence }\end{array}$ & $\begin{array}{l}\text { Overall } \\
\text { Credibility }\end{array}$ \\
\hline Pechtold-D66 & 1 & 2 & 1 & 1 & 3 \\
Rutte-VVD & 2 & 1 & 2 & 2 & 2 \\
Wilders-PVV & 3 & 4 & 3 & 3 & 4 \\
Timmermans-PvdA & 4 & 3 & 4 & 4 & 1 \\
\hline
\end{tabular}

Wilders' credibility, finally, is also medium, as the average scores on the three credibility dimensions range between 6.99 and 7.63. In particular, his followers judge his perceived caring as relatively low. Consequently, it can be argued that Wilders is considered to only moderately relate to his party's supporters concerns and ideas.

\section{Conclusions}

This article started out by noting that academic studies find, at most, mixed evidence for the perceived gap between leaders' and citizens' views on Europe that features so prominently in the public debate. Using the technique of cognitive mapping with its focus on the narrative underlying citizens' and leaders' positions, this study finds evidence of the existence of such a gap in the case of four Dutch leaders. While in terms of issue saliency the congruence is mixed and ranges between 42 to 64.5 percent of leaders' cognitive maps, the ideological distance between Timmermans and especially Wilders and their respective voters is considerable. Finally, the narrative congruence is far from complete but only in the case of Timmermans and his followers a true disconnect in their stories of Europe exists. This shows that the hierarchy of congruence does indeed hold: moving up the hierarchy reveals more evidence of a gap between leaders and voters. More importantly, narrative congruence reveals the overlap and differences in the argumentation behind leaders' and voters' score on issue saliency and ideological distance, and thereby informs us why a gap between leaders' and followers' assessment of the EU exists, or not.

In contrast, the study finds no support for the commonplace assumption that by being responsive to the will of the people, leaders will be seen as more credible by their followers. Particularly in the case of
Timmermans, who is seen as the most credible and caring by his party's supporters, his low scores on all three forms of congruence are striking (Table 5). The scores for Pechtold show a similar lack of impact of congruence on credibility as his speech-acts were most representative of the views of his voters, but his perceived credibility and especially caring was lower than expected. For Wilders the discrepancy is smaller, as he showed a considerable lack in congruence for issue saliency and ideological distance and a moderate narrative congruence, and his credibility is seen to be low. Only for Rutte the congruence scores do line up with his perceived credibility. Overall, however, none of the measures of congruence aligns plausibly with leaders' credibility in this study. Even in terms of caring, the subdimension of credibility that is theoretically linked most clearly with congruence, the scores do not line up.

This study also inspires some broader conclusions. Firstly, the study indicates that the technique of cognitive mapping, and especially the narratives it unveils, provides an interesting complement to the methodological tool-box of scholars interested in responsive leadership. The measure offers valuable additional insight in the normative evaluation of policy goals and instruments as well as into the argumentation behind leaders' and followers' position on contested issues like European integration. Secondly, although the lack of evidence for a connection between congruence and credibility is remarkable in light of commonplace assumptions in the literature, this article only includes a limited number of cases and respondents. Moreover, future research should keep in mind that while nowadays European integration is a very salient subject in the public debate, voters may have very different things on their mind and develop issue-specific measures for rating the credibility of political leaders. Reflecting on the remarkable support for Timmermans, for instance, raises the question of his position on oth- 
er issues but also on the role of non-cognitive factors in assessing leaders' credibility.

All in all, further study is needed to establish to what extent the findings in this article hold in general. Nonetheless, it does show that narrative congruence and the technique of cognitive mapping offer a valuable and viable way to measure the responsiveness of political leaders to the concerns of their followers. Moreover, in a timeframe in which voicing the will of the people is often seen as a prime commodity for political leaders, our findings-although tentative-may be a timely reminder that leadership is not only about reflecting the will of the people. It is also about taking the lead and guiding your followers into directions unknown. The case of Timmermans may indicate that in gaining the support of the people, this may be as much the missing link in European leadership as responsiveness.

\section{Acknowledgements}

The authors would like to thank Sebastiaan Steenman for his advice on the ideological distance measure.

\section{Conflict of Interests}

The authors declare no conflict of interests.

\section{References}

Arnold, C., Sapir, E. V., \& Zapryanova, G. (2012). Trust in the institutions of the European Union: A crosscountry examination. European Integration Online Papers, Special Mini-Issue 2(16), Article 8.

Axelrod, R. M. (1976). The cognitive mapping approach to decision making. In R. Axelrod (Eds.), Structure of decision: The cognitive maps of political elites (pp. 317). Princeton: Princeton University Press.

Bastian, M., Heymann, S., \& Jacomy, M. (2009). Gephi: An open source software for exploring and manipulating networks. International AAAl conference on weblogs and social media. Palo Alto, CA: Association for the Advancement of Artificial Intelligence Publications.

Berlo, D., Lemert, J., \& Mertz, R. (1969). Dimensions for evaluating the acceptability of message sources. Public Opinion Quarterly, 33(4), 563-576.

Best, R. E., Budge, I., \& McDonald, M. D. (2012). Representation as a median mandate: Taking cross-national differences seriously. European Journal of Political Research, 51(1), 1-23.

Bougon, M., Weick, K., \& Binkhorst, D. (1977). Cognition in organizations: An analysis of the Utrecht Jazz Orchestra. Administrative Science Quarterly, 22(4), 606639.

Carruba, C. J. (2001). The electoral connection in European Union politics. The Journal of Politics, 63(1), 141-158.
De Wilde, P., \& Zürn, M. (2012). Can the politization of European integration be reversed? Journal of Common Market Studies, 50(1), 137-153.

Dekker, P., \& Den Ridder, J. (2011). Stemming onbestemd. The Hague: SCP.

Esaiasson, P., \& Wlezien, C. (2016). Advances in the Study of Democratic Responsiveness: An Introduction. Comparative political studies, advance online publication, DOI: 10.1177/0010414016633226.

Flinders, M. (2012) Defending Politics. Why democracy matters in the twenty-first century. Oxford: Oxford University Press.

Gaxie, D., Hubé, N., \& Rowell, J. (2011). Perceptions of Europe: A comparative sociology of European attitudes. Colchester: ECPR Press.

Golder, M., \& Stramsky, J. (2010). Ideological congruence and electoral institutions. American Journal of Political Science, 54(1), 90-106.

Gwet, K. L. (2012). Handbook of inter-rater reliability: The definitive guide to measuring the extent of agreement among multiple raters. Gaithersburg, MD: Advanced Analytics Press.

Hay, C. (2007). Why we hate politics. Cambridge: Polity Press.

Hendriks, F., Van der Krieken, K., Van Zuydam, S., \& Roelands, M. (2016). Bewegende beelden van democratie: Legitimiteitsmonitor Democratisch Bestuur 2015. The Hague: Ministry of the Interior and Kingdom relations.

Hobolt, S. B., \& Klemmemsen, R. (2005). Responsive government? Public opinion and government policy preferences in Britain and Denmark. Political studies, 53, 379-402.

Hodgkinson, G. P., Maule, A. J., \& Bown, N. J. (2004). Causal cognitive mapping in the organizational strategy field: A comparison of alternative elicitation procedures. Organizational Research Methods, 7(1), 326.

Hooghe, L., \& Marks, G. (2009). A postfunctionalist theory of European integration: From permissive consensus to constraining. British Journal of Political Science, 39(1), 1-23.

Hovland, C., Janis, I., \& Kelley, H. (1953). Communication and persuasion. New Haven: Yale University Press.

Jacobs, L., \& Shapiro, R. (2000). Politicians don't pander: Political manipulation and the loss of democratic responsiveness. Chicago: University of Chicago Press.

Laukkanen, M., \& Wang, M. (2015). Comparative causal mapping: The CMAP3 method. Farnham: Ashgate Publishing.

Levi, M., \& Stoker, L. (2000). Political trust and trustworthiness. Annual Review of Political Science, 3, 475507.

Lijphart, A. (1999). Patterns of democracy: Government forms and performance in thirty-six countries. New Haven: Yale University Press.

Lindeboom, G (2012). Public priorities in government's 
hands: Corresponding policy agendas in the Netherlands. Acta Politica, 47, 443-467.

Manin, B. (1997). The principles of representative government. Cambridge: Cambridge University Press.

Mayne, Q., \& Hakhverdian, A. (forthcoming). Ideological congruence and citizen satisfaction: Evidence from 25 advanced democracies. Comparative Political Studies.

McCroskey, J. C., \& Teven, J. J. (1999). Goodwill: A reexamination of the construct and its measurement. Communications Monographs, 66(1), 90-103.

Miller, A. H., \& Listhaug, O. (1999). Political performance and institutional trust. In P. Norris (Eds.), Critical citizens: Global support for democratic governance (pp. 204-216). Oxford: Oxford University Press.

Norris, P. (2011). Democratic deficits: Critical citizens revisited. Cambridge: Cambridge University Press.

O'Keefe, D. (1990). Persuasion: Theory and research. London: Sage Publications.

Ray, L. (2003). When parties matter: The conditional influence of party positions on voter opinions about European integration. The Journal of Politics, 65(4), 978-994.

Pechtold, A. (2012). Koers houden is de beste traditie: Over vooruitgang en nieuw optimisme. Kerdijklezing, $3^{\text {rd }}$ November.

Pechtold, A. (2014a). Congresspeech. $99^{\text {th }}$ D66 Congress, Amsterdam, February $7^{\text {th }}$.

Pechtold, A. (2014b). Staat van de unie. The Hague, March $31^{\text {st }}$.

Reicher, S., Haslam, S., \& Platow, M. (2014). Social psychological study of leadership. In R. A. W. Rhodes \& P. 't Hart (Eds.), Oxford handbook of political leadership (pp. 149-160). Oxford: Oxford University Press.

Schaffer, F. C. (2010). Thin descriptions: The limits of survey research on the meaning of democracy. (Political Concepts-Committee on Concepts and Methods Working Paper Series, no. 45). Mexico City, Mexico: C\&M, IPSA, CIDE.

Rutte, M. (2013). Nederland bij de tijd brengen: Verandering en zekerheid. H.J. Schoo-lezing, Amsterdam, June $25^{\text {th }}$.

Rutte, M. (2014a). Speech on Europe. FriedrichNaumann-Stiftung, April $3^{\text {rd }}$.

Rutte, M. (2014b). Smart EU regulation, better business. The Hague, May $7^{\text {th }}$.

Stake, R. (1995). The art of case study research. Thousand Oaks: Sage Publications.

Startin, N., \& Krouwel, A. (2013). Euroscepticism re-galvanized: The consequences of the 2005 French and Dutch rejections of the EU Constitution. Journal of Common Market Studies, 51(1), 65-84.

Steenbergen, M. R., Edwards, E. E., \& De Vries C. E. (2007). Who's cueing whom? Mass-elite linkages and the future of European integration. European Union Politics, 8(1), 13-35.

Thomassen, J. (1994). Empirical research into political representation: Failing democracy or failing models? In M. K. Jennings \& T. Mann (Eds.), Elections at home and abroad (pp. 237-264). Ann Arbor: The University of Michigan Press.

Timmermans, F. (2013). Keynote conference. Networking European Citizenships, The Hague, November $14^{\text {th }}$.

Timmermans, F. (2014a). Europaspeech. Rotterdam, February $19^{\text {th }}$.

Timmermans, F. (2014b). Europe's Eastern Border: Using Realpolitik to Achieve Our Ideals. Amsterdam, September $2^{\text {nd }}$.

Van den Berg, C., \& Van Eijk, C. (2012). Van permissive consensus tot political by-pass: De politisering van de EU in Nederland. In P. de Jong \& S. de Lange (Eds.), Europa, burgerschap en democratie: Over de gespannen relatie tussen burgers en Europa en de mogelijkheden om die te ontspannen (pp. 41-56). The Hague: Raad voor het Openbaar Bestuur.

Van Esch, F. A. W. J. (2014). Exploring the keynesianordoliberal divide: Flexibility and convergence in French and German leaders' economic ideas during the Euro-crisis. Journal of Contemporary European Studies, 22(3), 288-302.

Van Ingelgom, V. (2014). Integrating indifference: A comparative, qualitative and quantitative approach to the legitimacy of European integration. Colchester: ECPR Press.

Van Zuydam, S. (2014). Democratic trust under pressure: Credibility of cabinet ministers and parliamentary party leaders [Dataset]. Tilburg: CenterData.

Verba, S., \& Nie, N. H. (1972). Participation in America. New York: Little, Brown \& Co.

Walczak, A., \& Van der Brug, B. (2012). Representation in the European Parliament: Factors affecting the attitude congruence of voters and candidates in the EP elections. European Union Politics, 14(1), 3-22.

Wilders, G. (2013) The resurgence of national pride and the future of Europe. Los Angeles, June $9^{\text {th }}$.

Wilders, G. (2014a) Wij zijn allemaal Vlamingen. Vlaams Belang, March $23^{\text {rd }}$.

Wilders, G. (2014b) Interview. N-TV.de, May $5^{\text {th }}$.

Wrightson, M. T. (1976). The documentary coding method. In R. Axelrod (Ed.), Structure of decision: The cognitive maps of political elites (pp. 291-332). Princeton: Princeton University Press.

Young, M. D., \& Schafer, M. (1998) Is there method in our madness? Ways of assessing cognition in international relations. Mershon International Studies Review, 42(1), 63-96. 


\section{About the Authors}

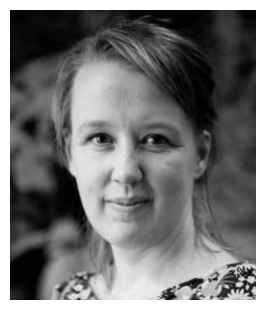

Femke van Esch is an Associate Professor of European Integration at the Utrecht School of Governance, Utrecht University. She specialises in the study of European Economic and Monetary Affairs and leadership in the European Union. Her work has appeared in such journals as West European Politics, Journal of Common Market Studies and European Political Science Review. She is workpackage leader in the Horizon2020 TransCrisis research project managing a large-scale research project on the sensemaking of political leaders during the Eurocrisis.

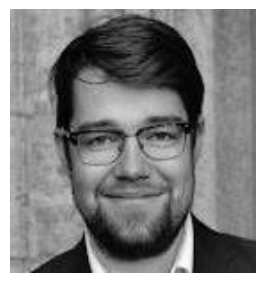

Rik Joosen is a student assistant at the Utrecht School of Governance of Utrecht University and a student of the master Research in Public Administration and Organisational Science at Utrecht University. His main academic interests are European integration, European leadership, representative democracy, European Union institutions \& regulatory governance. He currently works on the TransCrisis project, funded by the Horizon 2020 programme, studying political leaders in the Eurocrisis.

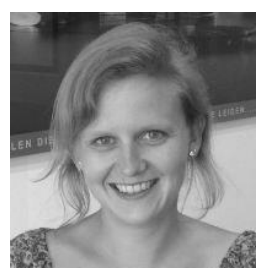

Sabine van Zuydam is a PhD researcher at the Tilburg School of Politics and Public Administration (Tilburg University). Her research interests include political leadership, framing, dramaturgy, politicsmedia relations, and local governance. In her PhD project on credible political leadership she focuses on why cabinet ministers and parliamentary party leaders are deemed credible by citizens. In addition, she has studied the Dutch mayor, democratic legitimacy, and the credibility of regional cooperation. 